\title{
Evidence of climatic adaptation in spontaneous torpor among Pouched mice Saccostomus campestris from southern Africa
}

\author{
George T. H. ELLISON*
}

Ellison G. T. H. 1993. Evidence of climatic adaptation in spontaneous torpor among Pouched mice Saccostomus campestris from southern Africa. Acta theriol. 38: 49-59.

Spontaneous torpor was examined in 36 Pouched mice Saccostomus campestris Peters, 1846 from 6 localities in southern Africa. Fifteen individuals displayed characteristic bouts of torpor in which oxygen consumption $\left(\dot{\mathrm{V}}_{2}\right)$ fell below $50 \%$ of the resting levels of non-torpid pouched mice for more than $2 \mathrm{hr}$ during the early morning. These bouts ended in an abrupt increase in $\dot{\mathrm{VO}}_{2}$ which overshot resting levels during arousal to normothermia. Minimum oxygen consumption $\left(\dot{\mathrm{V}} \mathrm{O}_{2 \mathrm{~min}}\right)$ was not correlated with the energy saved during torpor, but there was a significant positive correlation between $\dot{\mathrm{V}} \mathrm{O}_{2 \min }$ and the duration of torpor $\left(\mathrm{D}_{t}\right)$ and also between $\mathrm{D}_{t}$ and energy saved. In contrast, there was a negative correlation between the cost of arousal and energy saved which suggests that the cost of regaining homeothermy can limit the energetic efficiency of short bouts of torpor. Pouched mice from all 6 localities had the capacity to enter torpor and there were no significant geographical differences in the incidence of torpor. However, there were substantial differences in the expression of torpor, and Pouched mice from localities experiencing more variable temperatures underwent significantly longer bouts of torpor which suggests that selection for torpor had been greater in more energetically unpredictable environments.

Mammal Research Institute, University of Pretoria, Pretoria 0002, South Africa

Key words: Saccostomus campestris, spontaneous torpor, climatic adaptation, southern Africa

\section{Introduction}

Small mammals face a substantial increase in heat loss when subjected to cold stress as a result of their large surface area to volume ratio (Hart 1971). Although this should cause higher thermoregulatory costs, heat loss can be reduced by improving thermal insulation, or by lowering body temperature and entering torpor so that the temperature gradient between ambient and body core is reduced (Vogt and Lynch 1982). Torpor is characterised by a drop in body temperature below $30^{\circ} \mathrm{C}$ followed by spontaneous arousal to normothermia (Hudson 1978) and can be elicited either by food restriction ("induced torpor", e.g. Buffenstein 1985) or cold stress ("spontaneous torpor", e.g. Hill 1975). According to Tannenbaum and

*Present address: School of Biological and Chemical Sciences, University of Greenwich, Wellington Street, Woolwich SE18 6PF, UK 
Pivorun (1988) "because small mammals from different environments do not experience identical seasonal fluctuations in stress-provoking stimuli it is reasonable to expect them to exhibit different tendencies toward torpor" and several studies have described geographical differences in the expression of torpor which are associated with differences in climatic conditions (Brenner and Lyle 1975, Hill 1975, Heath and Lynch 1983, Tannenbaum and Pivorun 1984, Thompson 1985).

Pouched mice Saccostomus campestris, Peters 1846 are small cricetíd rodents which are widespread in southern Africa (Smithers 1983) and enter torpor in response to cold stress (Ellison and Skinner 1992). In common with other subtropical, semi-fossorial mammals (Downs and Perrin 1989), S. campestris experience marked seasonal and geographical differences in temperatures above and below ground (Ellison 1993) and the aim of the present study was to investigate whether there are any differences in the expression of spontaneous torpor among Pouched mice from six localities with contrasting climatic conditions.

\section{Materials and methods}

\section{Animals}

Torpor was examined in Pouched mice which originated from six localities in southern Africa and displayed variable karyotypes (see Table 1 for details). Temperature data for each locality were generated using a climatic surface model developed for Africa by the Centre for Resource and Environmental Studies at the Australian National University in Canberra. The basic technique involves fitting mathematical surfaces to existing climatic station records using Laplacian smoothing splines with generalised cross-validation (Hutchinson et al. 1984). This provided the best available estimates of climatic conditions, particularly at localities far away from meteorological stations. Mean monthly minimum temperature $\left(\mathrm{T}_{\min }\right)$ was taken as the most relevant indication of the thermal environment experienced by pouched mice, as $\mathrm{T}_{\min }$ occurs at night, when these animals are active outside their burrows (Smithers 1983). At the same time, the coefficient of variation (Sokal and Rohlf 1981) of $T_{\min }$ was also calculated to provide an estimate of seasonal variability of temperature $\left(\mathrm{S}_{\mathrm{t}}\right)$ at each locality. These data have been summarised in Table 1.

Table 1. Summary of $S$. campestris localities examined and the temperature conditions therein.

\begin{tabular}{lccccc}
\hline $\begin{array}{l}\text { Locality } \\
\text { (Grid reference) }\end{array}$ & $\begin{array}{c}\text { Karyotype } \\
(2 \mathrm{n})\end{array}$ & $\begin{array}{c}\text { Mean body } \\
\text { mass } \pm \mathrm{SD} \\
(\mathrm{g})\end{array}$ & $\begin{array}{c}\text { Males: } \\
\text { Females } \\
(n: n)\end{array}$ & $\begin{array}{c}\text { Mean monthly } \\
\text { minimum } \\
\text { temperature } \\
\left(\mathrm{T}_{\min }\right)\end{array}$ & $\begin{array}{c}\text { Coefficient } \\
\text { of variation in } \\
\text { monthly minimum } \\
\text { temperature }\left(\mathrm{S}_{\mathrm{t}}\right)\end{array}$ \\
\hline Letaba $\left(23^{\circ} 56^{\prime} \mathrm{S}, 31^{\circ} 35^{\circ} \mathrm{E}\right.$ & 46 & $71.8 \pm 11.0$ & $3: 3$ & $16.8^{\circ} \mathrm{C}$ & $23.3 \%$ \\
Nwanedzi $\left(24^{\circ} 23^{\prime} \mathrm{S}, 31^{\circ} 40^{\circ} \mathrm{E}\right)$ & 46 & $81.9 \pm 11.3$ & $4: 2$ & $16.4^{\circ} \mathrm{C}$ & $23.8 \%$ \\
Gam $\left(20^{\circ} 27^{\prime} \mathrm{S}, 20^{\circ} 44^{\prime} \mathrm{E}\right)$ & 35 & $71.8 \pm 11.0$ & $3: 3$ & $13.6^{\circ} \mathrm{C}$ & $39.1 \%$ \\
Pniel $\left(28^{\circ} 35^{\prime} \mathrm{S}, 24^{\circ} 31^{\prime} \mathrm{E}\right.$ & 32 & $75.9 \pm 13.1$ & $3: 3$ & $10.0^{\circ} \mathrm{C}$ & $60.5 \%$ \\
Schuinklip $\left(28^{\circ} 51^{\prime} \mathrm{S}, 19^{\circ} 42^{\prime} \mathrm{E}\right)$ & 35 & $49.8 \pm 6.3$ & $2: 4$ & $11.1^{\circ} \mathrm{C}$ & $47.9 \%$ \\
Vaalkop $\left(25^{\circ} 23^{\prime} \mathrm{S}, 2^{\circ} 28^{\circ} \mathrm{E}\right)$ & 44 & $79.9 \pm 18.0$ & $3: 3$ & $11.7^{\circ} \mathrm{C}$ & $48.0 \%$ \\
\hline
\end{tabular}


A total of 36 Pouched mice, comprising 6 individuals from each locality, was studied. Eighteen individuals of each sex were used and approximately equal numbers of these were derived from wild-caught $(n=17)$ and first generation laboratory-bred $(n=19)$ stocks. Laboratory-bred mice were reared under long photoperiod (14L:10D) at $25^{\circ} \mathrm{C}$ and were at least 4 months old at the start of the present study. Wild-caught animals had been exposed to similar conditions for at least 4 months before the experiments began.

Throughout the present study the Pouched mice were housed separately in standard laboratory rat cages and provided with rabbit pellets, rat cubes (Epol, Vereeniging) and water ad libitum, a diet occasionally supplemented with sunflower seeds and pieces of apple. Shredded paper and sawdust were provided for bedding and their cages were cleaned weekly, and dusted with insecticide to eradicate ectoparasites (Karbadust: Sentrachem, Silverton. Containing $50 \mathrm{~g} / \mathrm{kg}$ Carbamate). Relative humidity was maintained above $45 \%$ to prevent ringtail (Ellison and Westlin-van Aarde 1990).

\section{Acclimation}

Although previous studies have confirmed that $S$. campestris enter spontaneous torpor at cold temperatures $\left(5-15^{\circ} \mathrm{C}\right.$; Ellison and Skinner 1992), short photoperiod seems to facilitate torpor in this species because more individuals enter torpor when acclimated to short photoperiod than when acclimated to long photoperiod (G. T. H. Ellison et al., unpubl.). In order to elicit torpor in as many animals as possible the Pouched mice in the present study were acclimated to short photoperiod (10L:14D) at $25^{\circ} \mathrm{C}$ for 4 weeks prior to cold acclimation (at $10^{\circ} \mathrm{C}-15^{\circ} \mathrm{C}$ ) under the same photoperiod.

Following 4 weeks cold acclimation the oxygen consumption $\left(\mathrm{V}_{2}\right)$ of each pouched mouse was recorded for $24 \mathrm{hr}$ at $10^{\circ} \mathrm{C}$ to determine the incidence, depth, duration and relative energy savings of spontaneous torpor in $S$. campestris from each locality.

\section{Oxygen consumption}

$\dot{\mathrm{V}}_{2}$ was measured using an open-circuit system (as described by Withers 1977: Equation 3a) and assuming an $\mathrm{RQ}$ of 0.85 . The mice were placed in large (13 litre), perspex metabolic chambers, through which a flow of dried air (silica gel) was passed at a rate of $600 \mathrm{ml} / \mathrm{min}$. The chambers were immersed in a constant temperature water bath (Labotec, Isando), and a thermocouple (J-Type: Grant Instruments, Cambridge) within the chamber was used for monitoring its temperature. The water bath was covered by a light-tight hood and short photoperiod was maintained using an electric light connected to an automatic time switch.

The Pouched mice were transferred to these chambers together with their bedding, food and water (fresh apple), at least $24 \mathrm{hr}$ prior to the start of measurement to allow them to become habituated to their new surroundings. $\mathrm{VO}_{2}$ was subsequently recorded every $30 \mathrm{~min}$ for $24 \mathrm{hr}$.

Following full equilibration of the system, the air leaving the chambers was dried and its oxygen content determined using an Ametek S-3A/I oxygen analyser (Applied Electrochemistry, Pittsburgh) connected to a multi-channel data logger (1200 Series Squirrel: Grant Instruments, Cambridge). An in-line, three way valve (Air/Water $350 \mathrm{KPA}$ : Ascoreg, Johannesburg) and time switch alternated the input to the oxygen analyser so that air from two chambers, containing separate Pouched mice, could be recorded twice an hour using a single oxygen analyser. The oxygen analyser was calibrated before and after each measurement and all readings were corrected to standard temperature and pressure, dry (STPD). Gross $\dot{\mathrm{V}} \mathrm{O}_{2}$ was converted to mass specific $\dot{\mathrm{V}}_{2}$ using the mean of body mass measurements taken at the beginning and end of each experiment.

To compensate for any differences in body mass, metabolic measurements were expressed in terms of [mass in grams] $]^{0.75}$ as suggested by Hart (1971). Average daily metabolic rate (ADMR) was calculated as the mean $\dot{\mathrm{V}} \mathrm{O}_{2}$ measured over a full $24 \mathrm{hr}$. Minimum metabolic rate $\left(\dot{\mathrm{V}}_{2 \mathrm{~min}}\right)$ was taken as the lowest value of $\dot{\mathrm{V}}_{2}$ sustained for at least 15 minutes during this period. 


\section{Body temperature}

Body temperature $\left(\mathrm{T}_{\mathrm{B}}\right)$ was measured in individuals from 3 localities (Letaba, Gam and Pniel) using small (1.2 g) temperature telemeters (Model X: Minimitter, Sunriver) which provided accurate temperature measurement to within $0.5^{\circ} \mathrm{C}$. Sterilised telemeters were surgically implanted in the peritoneal cavity of anaesthetised $(75 \mathrm{mg} / \mathrm{kg}$ i.p. Sagatal: Maybaker, Port Elizabeth) Pouched mice under veterinary supervision, and the mice were given at least 5 days to recover from surgery before measurements were made. The telemeters were calibrated prior to implantation and at the end of each experiment, during which time there was negligible drift of telemeter calibration.

Signals from implanted telemeters were received using small AM radios placed within the metabolic chambers. It wasn't possible to record $T_{B}$ continually because electromagnetic interference from laboratory equipment inhibited the reception of pulses from the minimitters. However, daily torpor usually takes place at a predictable time of day (Tucker 1965, Lynch and Gendler 1980) and previous studies have revealed that torpor cycles of Pouched mice always occur during the first few hours of photophase (Ellison and Skinner 1992). For this reason $\mathrm{T}_{\mathrm{B}}$ was recorded manually using headphones once an hour following lights on between 07.00 and 12.00 .

\section{Statistical procedures}

All results are presented as mean \pm one standard deviation. The Mann-Witney $U$-test ( $U-\mathrm{MWU}$ ), Chi-square test $\left(\chi^{2}-\mathrm{CS}\right)$ and Spearman's rank correlation coefficient $\left(r_{\mathrm{B}}-\mathrm{SCC}\right)$ were used for the statistical analysis of results (Sokal and Rohlf 1981).

\section{Results}

Body mass

Although Pouched mice from most localities exhibited a mean body mass (MB) of $70-80 \mathrm{~g}$ (Table 1) those from Schuinklip weighed only $49.8 \pm 6.3 \mathrm{~g}$ and were significantly smaller than individuals from other localities (MWU: $U<2, n_{1}=n_{2}$ $=6, p<0.01)$. Females $\left(\mathrm{M}_{\mathrm{B}}=67.6 \pm 14.2 \mathrm{~g}\right)$ were also smaller than males $\left(\mathrm{M}_{\mathrm{B}}=\right.$ $75.9 \pm 15.8 \mathrm{~g})$ whilst laboratory-bred mice $\left(\mathrm{M}_{\mathrm{B}}=71.5 \pm 13.8 \mathrm{~g}\right)$ were slightly smaller than wild-caught animals $\left(\mathrm{MB}_{\mathrm{B}}=73.8 \pm 16.4 \mathrm{~g}\right)$. However, these differences were not significant (Sex: $U=118.5, n_{1}=n_{2}=18, p>0.05$. Stock: $U=117.5, n_{1}=17$, $\left.n_{2}=19, p>0.05\right)$.

\section{Torpor cycles}

The TBs of 6 Pouched mice containing implanted telemeters (3 Gam, 2 Letaba and 1 Pniel) fell below $30^{\circ} \mathrm{C}$ and these animals were considered to have entered torpor (Hudson 1978). Their mean minimum $\mathrm{T}_{\mathrm{B}}$ was $24.7 \pm 2.5^{\circ} \mathrm{C}$ and ranged from $21.0^{\circ} \mathrm{C}$ to $27.5^{\circ} \mathrm{C}$. The ADMRs of these individuals were characterised by a distinct decline in $\mathrm{VO}_{2}$ during the early morning which fell below $50 \%$ of normothermic resting levels for more than $2 \mathrm{hr}$ and ended in a sharp increase in $\dot{\mathrm{V}} \mathrm{O}_{2}$ which overshot resting levels temporarily during arousal (Fig. 1). Similar bouts of reduced metabolism were displayed by 9 untelemetered Pouched mice ( 3 Nwanedzi, 3 Schuinklip and 3 Vaalkop) and daily variation in $\dot{\mathrm{V}}_{2}$ of these animals is also displayed in Fig. 1. Of those individuals which entered torpor, 6 were female and 9 were male, whilst 7 were laboratory-bred and 8 were wild-caught. These 


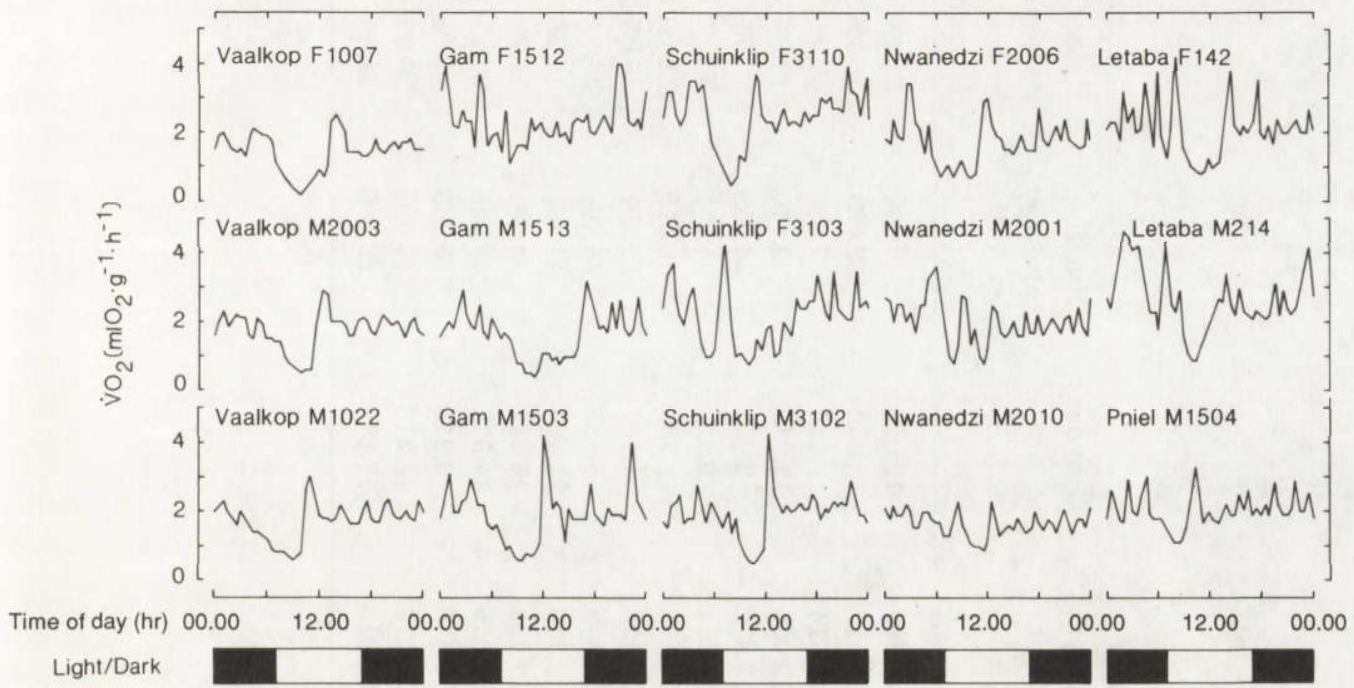

Fig. 1. Oxygen consumption $\left(\dot{\mathrm{V}}_{2}\right)$ of 15 Pouched mice recorded over $24 \mathrm{hr}$ at $\mathrm{T}_{\mathrm{a}}=10^{\circ} \mathrm{C}$. Each Pouched mouse exhibited a bout of spontaneous torpor which was characterised by a distinct decline in $\dot{\mathrm{V}}_{2}$ during the early morning which fell below $50 \%$ of resting levels for more than $2 \mathrm{hrs}$ and ended in a sharp increase in $\dot{\mathrm{V}}_{2}$ during arousal to normothermia.

proportions did not differ significantly from parity (CS: Sex: $\chi^{2}=0.013$; Stock: $\chi^{2}$ $=0.002, \mathrm{df}=1, p>0.05)$ and there was also no significant difference between the MB of Pouched mice which entered torpor $(73.4 \pm 19.4 \mathrm{~g})$ and those remaining normothermic (70.6 $\pm 12.1 \mathrm{~g}$. MWU: $\left.U=146, n_{1}=15, n_{2}=21, p>0.05\right)$.

In order to quantify the duration and relative energetic savings for each bout of torpor, the metabolism of torpid individuals was compared to that of euthermic Pouched mice from the same locality (see Ellison and Skinner 1992, and Fig. 2). Torpor duration $\left(\mathrm{D}_{\mathrm{t}}\right)$ was determined as the period during which the metabolism of torpid animals fell below the mean metabolism of non-torpid mice from the same locality measured during photophase (the resting phase of $S$. campestris). Likewise the duration of overshoot $\left(\mathrm{D}_{0}\right)$ was calculated as the period in which the metabolism of the arousing animal exceeded the mean metabolism of non-torpid mice measured during photophase. The energy savings of each bout of torpor were then determined by calculating the total oxgen consumption during torpor ( $\mathrm{T})$, the total oxygen consumption during overshoot $(\mathrm{O})$, and the equivalent oxygen consumption of non-torpid individuals over the same period of time $(\mathrm{N})$. The energy savings $(\mathrm{N}-[\mathrm{T}+\mathrm{O}])$ were then expressed as a percentage of $\mathrm{N}$. These data are summarised in Table 2 together with $\dot{\mathrm{V}}_{2 \mathrm{~min}}$ recorded.

As an indication of torpor depth, $\dot{\mathrm{V}} \mathrm{O}_{2 \min }$ was inversely correlated with torpor duration $\left(\mathrm{D}_{\mathrm{t}}\right)$ (SCC: $\left.r_{\mathrm{s}}=-0.705, n=15, p<0.01\right)$. However, there was no significant correlation bween $\dot{\mathrm{V}}_{2} \min$ and the energy saved during each bout of torpor $\left(r_{\mathrm{s}}=\right.$ $-0.243, n=15, p>0.05$ ), although there was a significant positive correlation 


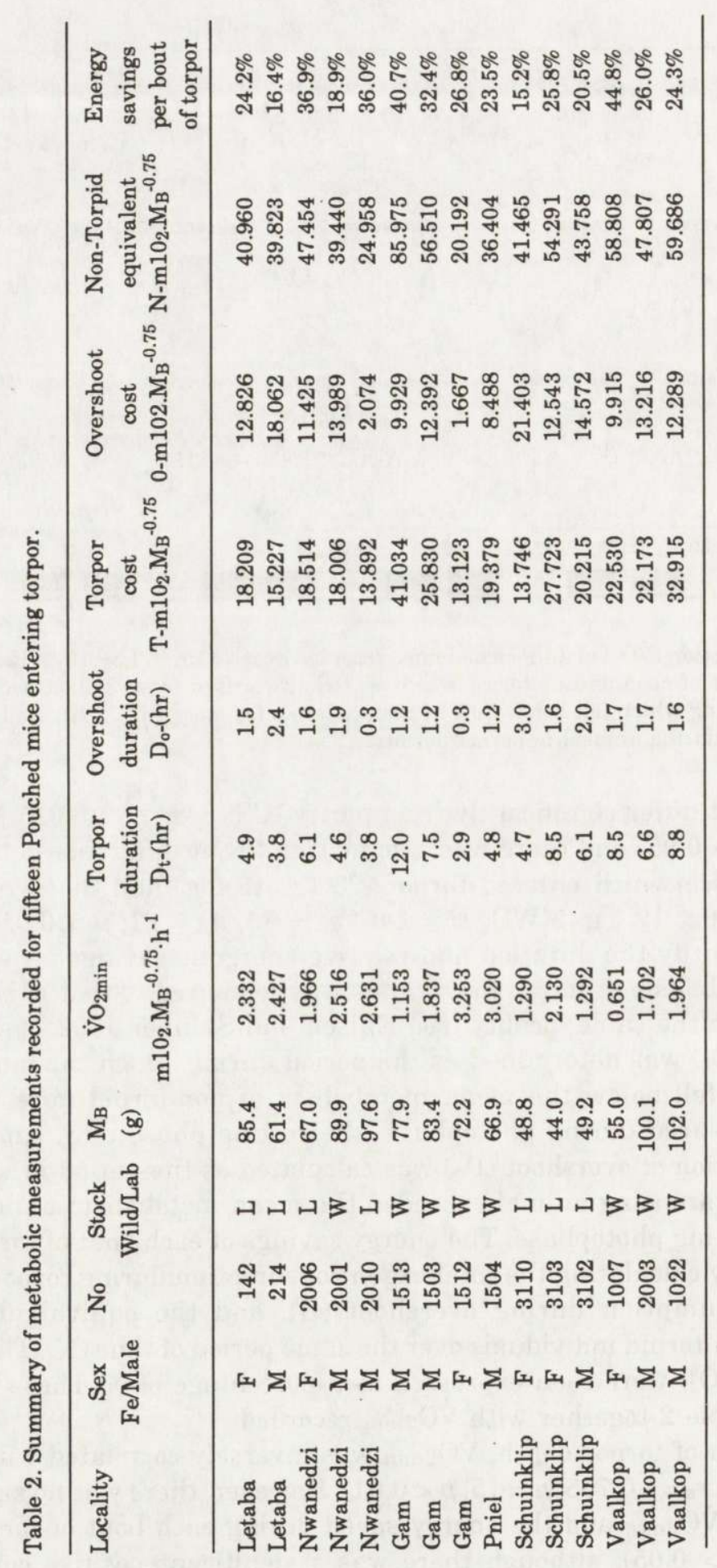




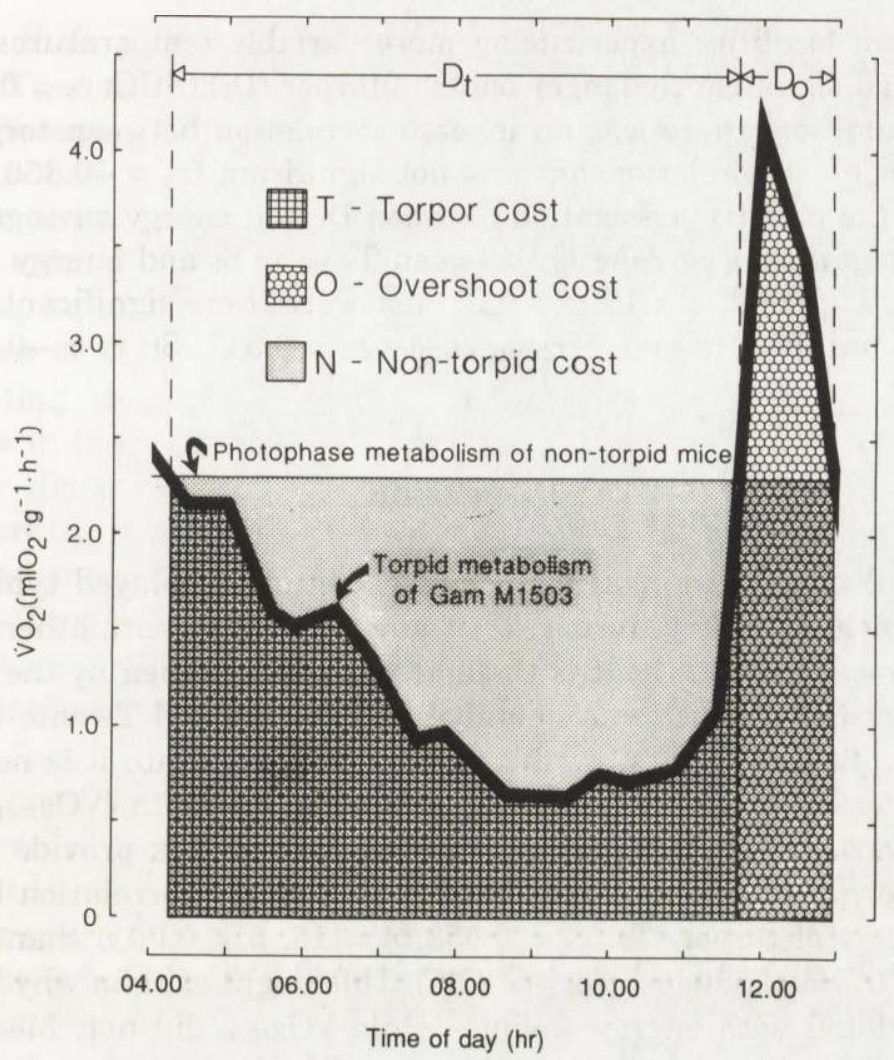

Fig. 2. Calculating the duration of torpor $\left(D_{t}\right)$, the duration of overshoot $\left(D_{0}\right)$, the cost of torpor $(T)$, the cost of overshoot $(\mathrm{O})$ and the equivalent cost of non-torpid pouched mice during the same period $(\mathrm{N})$ by comparing the oxygen consumption of a torpid individual (Gam 1503) to the mean oxygen consumption of non-torpid animals from the same locality recorded during photophase.

between energy savings and $\mathrm{D}_{\mathrm{t}}\left(r_{\mathrm{s}}=0.448, n=15, p>0.05\right)$. The duration of overshoot $\left(\mathrm{D}_{\mathrm{o}}\right)$ was positively correlated with its cost $(\mathrm{O})\left(r_{\mathrm{s}}=0.850, n=15, p<\right.$ $0.001)$ whilst $D_{0}$ and $O$ were both inversely correlated with energy savings $\left(D_{0}: r_{s}\right.$ $=-0.591, n=15, p<0.05$. O: $r_{\mathrm{s}}=-0.729, n=15, p<0.01$ ). Female Pouched mice did not display deeper or longer bouts of torpor than male animals (MWU: $U=$ 26.5/25.5, $n_{1}=6 n_{2}=9, p>0.05$ ) and did not accrue greater energy savings than males $\left(U=27, n_{1}=6, n_{2}=9, p>0.05\right)$. There was also no significant difference between laboratory-bred and wild-caught pouched mice with regard to these characteristics $\left(U>15, n_{1}=7, n_{2}=8, p>0.05\right)$.

\section{Geographical differences}

There were no significant geographical differences in the incidence of torpor among Pouched mice in the present study (CS: $\chi^{2}=3.800, \mathrm{df}=5, p>0.05$ ). However, there were substantial differences in the expression of torpor and 
individuals from localities experiencing more variable temperatures (i.e. higher values of $\mathrm{S}_{\mathrm{t}}$ ) had significantly longer bouts of torpor $\left(\mathrm{D}_{\mathrm{t}}\right)$ (SCC: $r_{\mathrm{s}}=0.465, n=15$, $p<0.05$ ). In addition, there was an inverse correlation between torpor duration and $\mathrm{T}_{\min }$ although this relationship was not significant $\left(r_{\mathrm{s}}=-0.350, n=15, p>\right.$ 0.05 ). Despite the positive association between $\mathrm{D}_{t}$ and energy savings (see above) there was no significant correlation between $\mathrm{T}_{\min }$ or $\mathrm{S}_{t}$ and energy saved $\left(\mathrm{T}_{\min }\right.$ : $\left.r_{\mathrm{s}}=0.134 ; \mathrm{St}_{\mathrm{t}} r_{\mathrm{s}}=0.062, n=15, p>0.05\right)$ nor were there significant correlations between these parameters and $\dot{\mathrm{V}}_{2 \min }\left(\mathrm{T}_{\min }: r_{\mathrm{s}}=0.317 ; \mathrm{St}: r_{\mathrm{s}}=-0.350, n=15\right.$, $p>0.05$ ).

\section{Discussion}

The Pouched mice examined in the present study displayed typical bouts of torpor which included entry, torpor itself and arousal to normothermia (Tucker 1965). The duration of each bout is thought to be determined by the depletion of nutrients and/or the production of metabolites (Twente and Twente 1965, Geiser 1988). As both of these factors are dictated by metabolic rate it is not surprising that the duration of torpor was inversely related to its depth $\left(\dot{\mathrm{V}}_{2 \mathrm{~min}}\right)$. However, because $\dot{\mathrm{VO}}_{2}$ varied during torpor, $\dot{\mathrm{V}}_{2 \text { min }}$ did not always provide an accurate indication of torpid metabolism and there was a closer correlation between the duration and cost of torpor ( $\mathrm{T})\left(r_{\mathrm{s}}=0.958, n=15, p<0.001\right)$ than between its depth and cost $\left(r_{\mathrm{s}}=-0.550, n=15, p>0.05\right)$. This might explain why the duration of torpor correlated with energy savings while $\dot{\mathrm{V}} \mathrm{O}_{2 \min }$ did not. Meanwhile, the inverse relationship between the cost of arousal and energy saved supports the suggestion by Prothero and Jürgens (1986) that the cost of regaining homeothermy can limit the energetic benefits of short bouts of torpor.

Several studies have previously reported geographical variation in the incidence of torpor between different populations of identical or closely related rodent species (Brenner and Lyle 1975, Hill 1975, Heath and Lynch 1983, Thompson 1985, Tannenbaum and Pivorun 1984, 1987, 1988). In each case, animals from warmer localities rarely entered torpor or did so in fewer numbers than those from colder areas, which suggests that selection for torpor was greater in more energetically stressful environments (Tannenbaum and Pivorun 1988). In the present study, there were no such geographical differences in the proportion of Pouched mice entering torpor and a similar number of individuals from populations throughout southern Africa had the capacity to exhibit torpor. However, there were significant geographical differences in torpor duration which are similar to those reported for Peromyscus species by Tannenbaum and Pivorun (1984). In their study $P$. maniculatus, from a montane habitat, had significantly longer bouts of torpor than two lowland species (P. leucopus and $P$. gossypinus) even though, like $S$. campestris in the present study, there were no differences in torpor depth (as determined by minimum body temperature). 
Although their original study was conducted upon acclimatized, wild-caught individuals, Tannenbaum and Pivorun subsequently confirmed the genetic basis for these differences by repeating the measurements on laboratory-bred animals (Tannenbaum and Pivorun 1987). In the present study there is strong evidence that the differential expression of torpor by $S$. campestris is also heritable: firstly, wild-caught animals had been subjected to extensive acclimation and secondly, approximately equal proportions of laboratory-bred and wild-caught mice entered torpor. In view of the variable karyotype displayed by S. campestris (Gordon 1986) it is interesting to speculate whether these karyotypic differences might have played a role in the differential expression of torpor as proposed by Lyman et al. (1983). They discovered significantly different torpor frequencies in two populations of Turkish hamsters Mesocricetus brandti from similar habitats, only 125 $\mathrm{km}$ apart, and suggested that these differences might be attributable to variation in karyotype (Lyman et al. 1983). This seems even more feasible for S. campestris as different karyotypic forms of this species appear to be associated with different biogeographical areas (Gordon 1986). However, two or more diploid numbers are occasionally found in the same locality (Gordon 1986) which indicates that the relationship between climate and karyotype is ill-defined and unlikely to be the cause of the differences in torpor described in the present study.

As Pouched mice accrue considerable savings in energy expenditure during bouts of torpor the increase in torpor duration at localities experiencing more variable temperatures might be interpreted as an adaptation to reduce thermoregulatory costs in unpredictable environments. Nevertheless, the adaptive significance of geographical variation in spontaneous torpor remains unclear because Pouched mice only enter spontaneous torpor at $15^{\circ} \mathrm{C}$ and below (Ellison and Skinner 1992) yet these temperatures are much lower than those recorded at burrows throughout South Africa, even during winter at the coldest locality (Ellison 1993). For this reason, it is tempting to suggest that the correlation between temperature variability and torpor duration is spurious, unless it indicates that pouched mice have experienced more severe conditions during their evolutionary history. Having evolved more than 3.5 million years ago (Denys 1988) $S$. campestris would have experienced at least 17 glacial periods since the middle of the Pliocene (Brain 1985) during which lower global temperatures might have favoured animals capable of longer bouts of torpor.

Acknowledgements: My thanks to Prof J. D. Skinner for his support, to B. Potgieter for technical assistance, and to J. Sebotse and I. Lethlage who took care of the mice. N. Bezuidenhout, H. Erasmus, M. and P. Linger, J. Pallett, Dr N. Rautenbach, K. Sheppey, and A. van Rooyen helped collect the Pouched mice while G. Bronner and S. Ferreira karyotyped these. Dr A. McKenzie (BVSc) supervised surgical procedures and ZS6BJH, ZS6ABM, and Dr W. Ferguson helped improve minimitter reception. Prof H. Nix and Dr J. McMahon generated the climatic data used, and Dr S. Buffenstein, Dr H. Dott and Dr W. Ferguson critically reviewed an earlier draft. The Foundation for Research Development, Department of National Education and University of Pretoria provided financial support. 


\section{References}

Brain C. K. 1985. Temperature-induced environmental changes in Africa as evolutionary stimuli. [In: Species and speciation. E. S. Vrba, ed]. Transvaal Mus. Monogr. 4: 45 - 52.

Brenner F. J. and Lyle P. D. 1975. Effect of previous photoperiodic conditions and visual stimulation on food storage and hibernation in the eastern chipmunk (Tamias striatus). Am. Midl. Nat. 93: $227-234$.

Buffenstein R. 1985. The effect of starvation, food restriction and water deprivation on thermoregulation and average daily metabolic rates in Gerbillus pusillus. Physiol. Zool. 58: 320 - 328.

Denys C. 1988. Apports de l'analyse morphométrique à la détermination des espèces actuelles et fossiles du genre Saccostomus (Cricetomyinae, Rodentia). Mammalia 5: 497 - 532.

Downs C. T. and Perrin M. R. 1989. An investigation of the macro- and micro- environments of four Gerbillurus species. Cimbebasia 11: $41-54$.

Ellison G. T. H. 1993. Group size, burrow structure and hoarding activity of pouched mice (Saccostomus campestris: Cricetidae) in southern Africa. Afr. J. Ecol. 31: (in press).

Ellison G. T. H. and Skinner J. D. 1992. The influence of ambient temperature on spontaneous daily torpor of pouched mice (Saccostomus campestris: Rodentia - Cricetidae) from southern Africa. J. therm. Biol. 17: $25-31$.

Ellison G. T. H. and Westlin-van Aarde L. M. 1990. Ringtail in the pouched mouse (Saccostomus campestris). Lab. Anim. 24: $174-175$.

Geiser F. 1988. Reduction of metabolism during hibernation and daily torpor in mammals and birds: temperature effect or physiological inhibition? J. Comp. Physiol. B 158: 25 - 37.

Gordon D. H. 1986. Extensive chromosomal variation in the pouched mouse Saccostomus campestris (Rodentia, Cricetidae) from southern Africa: A preliminary investigation of evolutionary status. Cimbebasia 8: $37-47$.

Hart J. S. 1971. Rodents. [In: Comparative physiology of thermoregulation. G. C. Whittow, ed]. Academic Press, New York: 1 - 149.

Heath H. W. and Lynch G. R. 1983. Intraspecific differences in the use of photoperiod and temperature as environmental cues in white-footed mice Peromyscus leucopus. Physiol. Zool. 56: $506-512$.

Hill R. W. 1975. Daily torpor in Peromyscus leucopus on an adequate diet. Comp. Biochem. Physiol. 51A: $413-423$.

Hutchinson M. F., Booth T. H., McMahon J. P. and Nix H. A. 1984. Estimating monthly mean values of daily total solar radiation for Australia. Solar Energy 32: 277 - 290.

Hudson J. W. 1978. Shallow daily torpor. [In: Strategies in cold. L. C. H. Wang and J. W. Hudson, eds]. Academic Press, New York: 67 - 108.

Lyman C. P., O’Brien R. C. and Bossert W. H. 1983. Differences in tendency to hibernate among groups of Turkish hamsters (Mesocricetus brandti). J. therm. Biol. 8: 255 - 257.

Lynch G. R. and Gendler S. L. 1980 Multiple responses to different photoperiods occur in the mouse, Peromyscus leucopus. Oecologia 45: $318-321$.

Prothero J. and Jürgens K. D. 1986. An energetic model of daily torpor in endotherms. J. Theor. Biol. 121: $403-415$.

Smithers R. H. N. 1983 The mammals of the southern African subregion. University of Pretoria Press, Pretoria: $1-283$.

Sokal R. R. and Rohlf F. J. 1981. Biometry. W. H. Freeman \& Co, San Francisco: 1 - 859.

Tannenbaum M. G. and Pivorun E. B. 1984. Differences in daily torpor patterns among three southeastern species of Peromyscus. J. Comp. Physiol. B 154: 233 - 236.

Tannenbaum M. G. and Pivorun E. B. 1987. Differential effect of food restriction on the induction of daily torpor in Peromyscus maniculatus and P. leucopus. J. therm. Biol. 12: 159 - 162. 
Tannenbaum M. G. and Pivorun E. B. 1988. Seasonal study of daily torpor in southeastern Peromyscus maniculatus and Peromyscus leucopus from mountains and foothills. Physiol. Zool. 61: $10-16$.

Thompson S. D. 1985. Subspecific differences in metabolism, thermoregulation, and torpor in the western harvest mouse, Reithrodontomys megalotis. Physiol. Zool. 58: 430 - 444 .

Tucker V. A. 1965. The relation between the torpor cycle and heat exchange in the California pocket mouse, Perognathus californicus. J. Cell. Comp. Physiol. 65: 405 - 414.

Twente J. W. and Twente J. A. 1965. Effects of core temperature upon duration of hibernation of Citellus lateralis. J. Appl. Physiol. 20: 411 - 416.

Vogt F. D. and Lynch G. R. 1982. Influence of ambient temperature, nest availability, huddling and daily torpor on energy expenditure in the white- footed mouse Peromyscus leucopus. Physiol. Zool. 55: $56-63$.

Withers P. C. 1977. Measurement of $\mathrm{V}_{2}, \dot{\mathrm{VCO}}_{2}$, and evaporative water loss with a flow-through mask. J. Appl. Physiol. 42: 120 - 123.

Received 20 October 1992, accepted 15 March 1993. 